\title{
A Comparative Study on the Effects of Enzymes Feed Additive "Kemzyme" and Antibiotic Growth Promoter "Salinomycin" on Haemostatic Mechanism of Rabbit Bucks
}

\author{
F. A. Bughdadi ${ }^{1}$, K. A. Attia ${ }^{1,2} \&$ Sohair Y. Saleh ${ }^{2}$ \\ ${ }^{1}$ Department of Biology, University College, Umm Al-Qura University, Makkah, Saudi Arabia \\ ${ }^{2}$ Department of Physiology, Faculty of Veterinary Medicine, Cairo University, Giza, Egypt \\ Correspondence: Faisal A. Bughdadi, Department of Biology, University College, Umm Al-Qura University, \\ Makkah, Saudi Arabia. Tel: 966-553-515-007. E-mail: fabughdadi@uqu.edu.sa
}

\author{
Received: October 11, 2013 Accepted: November 19, 2013 Online Published: December 15, 2013 \\ doi:10.5539/jas.v6n1p161 URL: http://dx.doi.org/10.5539/jas.v6n1p161
}

\begin{abstract}
The present study was designed to investigate the effects of enzymes (Kemzyme) or antibiotic (Salinomycin) feed additives on haemostatic mechanism and some haemostatic parameters in rabbit bucks. Twenty four rabbit bucks of average age 4 months were used and allocated into 3 equal groups (8/ each); control un-supplemented, Kemzyme and Salinomycin supplemented groups. The supplements were mixed with the ration for 8 successive weeks. Blood samples were collected at the end of the $4^{\text {th }}$ and the $8^{\text {th }}$ weeks of the experiment. Results obtained revealed that: 1) Kemzyme supplementation was not associated with any significant alterations in the measured parameters and 2) at the end of the $8^{\text {th }}$. week, salinomycin adversely affected the haemostatic mechanism in the form of hypocoagulabe state manifested by a significant increase in PT and APTT with a significant decrease in coagulation factors VII, IX and X activities. It could be concluded that kemzyme is a more safer feed additive. While, salinomycin should not be used for more than 4 weeks to avoid its adverse effect on haemostasis that could be a cause of sudden death resulting in economic losses or rendering the rabbit meat unmarketable due to inter and intramuscular patches of bleeding.
\end{abstract}

Keywords: feed additive, haemostasis, kemzyme, rabbits, salinomycin

\section{Introduction}

One of the major developmental challenges facing most developing countries is their inability to adequately feed their over increasing population with the right proportion of animal protein. The development of poultry industry has been described as the fastest mean of bridging the protein deficiency problem prevailing in most developing countries.

In recent years many efforts are directed for improving poultry industry by increasing of animal performance ; using growth promoters and feed additives as well as successful disease control besides increasing attention on improving the nutritional quality of poultry meat (Bogosavljević-Bošković et al., 2012).

Since long time ago, antibiotics have been used, either alone or in combination, as growth promoters. The addition of antibiotics in poultry feed was found to improve their performance, feed conversion and daily body gain with reduced mortality rate. However, concerns were raised that the use of antibiotics for growth promotion could lead to a problem of increasing resistance for bacteria of human and animal origin (Butaye et al., 2003).

Enzymes have been used as feed supplements for more than 50 years, but the rapid growth in their use has only been within the last 10 years (Tuoyin, 2005).Enzymes are considered as an alternative to some growth promoters as hormones and antibiotics with higher profits and quality of poultry products (Officer, 2000; Cowieson, 2005), that help poultry producers to adapt the forth coming European ban on antibiotic growth promoters as they can replace them and meet the increasing consumer demand for safe and affordable food. Scientists have demonstrated the value of feed enzymes in improving nutrient digestibility and bird's performance. They attributed their effects to the fact that many feed ingredients are not fully digested by live stock (Hruby, 2005). However; adding enzymes to feed enhanced digestibility of these components, improve the efficiency of existing 
formulation and lower their costs (Ghazi et al., 2002; Peter et al., 2002; Onderci et al., 2006; Cowieson \& Ravindran, 2008).

Rabbits have been recognized to have a very important role to play in the supply of animal protein to humans, especially in tropical and subtropical areas. Simple biological characteristics, short breeding cycle, high prolificacy and better feed conversion efficiency logically place rabbit just below poultry (Hasanat et al, 2006). The possibility of using exogenous enzymes in non-ruminant diets, reduces environmental pollution and lower feed costs (Zakaria et al., 2010). Several studies have been attempted for incorporating exogenous enzymes into rabbit diets to improve nutrients availability, however in most trials, rabbits appeared lapsable responsive and variable effects were observed on their performances (Garcia et al., 2005; Falcao-e-Cunha et al., 2007). Rabbits are herbivores and can be successfully raised on diets that are low in grains and high in roughage. Many experiments have indicated that, high cellulose diet was favorable for depressing death rate, the mechanism of action is to stimulate ileum, appendix vigor. The poor green grass unbalanced forage based diets offered at ad-libitum, are usually provided to rabbits in developing countries was described by Cheeke et al. (1985). Despite these obvious advantages, improved feed formulation and strategies for enhancing the production and reproduction potentials of rabbit especially in tropical and subtropical regions of the world have not been fully exploited.

The present study was aimed to investigate and compare between the effects of antibiotic growth promoters and enzymes feed additive supplementation on haemostatic mechanism and some haemostatic elements of rabbit bucks.

\section{Materials and methods}

\subsection{Animals, and Location:}

Twenty four male New Zealand White bucks of about 4-months age and average body weight $2.400 \mathrm{~kg}$ were used during June to August/2013. The animals were kept in individual cages, with free rabbit chow and water. Daily lighting regime was 10-12 hour photoperiod /day through both natural and fluorescent lighting. Animals were divided randomly to three groups (8/ each).

First group; was considered as a control group $(\mathrm{C})$ and fed on a commercial pelleted diet (Atmida Feed Company, Egypt).

The second group (K), the animals were supplemented with $0.1 \%$ "Kemzyme", a multi-enzyme blend (Liu, 2001).

The third group (S), the animals were supplemented with Salinomycin powder in a dose equal to100 $\mathrm{mg} / \mathrm{kg}$ ration (Chapman et al., 1993).

\subsection{Feed Additives:}

Kemzyme: a multi-enzyme feed additive containing proteases, $\alpha$ amylase, $\beta$ glucanas, Proteas, lipase, cellulase and xylanase, produced by "Kemin Agrifood Europe" and obtained as a powder from "Kemin Company, Egypt".

Salinomycin: it is an ionophore antibiotic growth promoter obtained as a powder, containing $4 \%$ active drug, from "Hoechest-RousselAgri-Vet. Co. Frankfurt, Germany. Doses of supplemented additives were mixed with the basal ration pellets.

\subsection{Feed}

All animal were raised on basal pelleted diet consisted of a concentrate mixture adequate in protein, energy, vitamins and minerals to meet the nutrient requirements of rabbit A commercial pelleted diet of $16.7 \%$ crude protein, $13.7 \%$ crude fiber and $2590 \mathrm{kcal}$ of digestible energy per kg (Atmida Feed Company, Egypt)was used . In addition, animal were offered green darrahwa (green corn) and they had free access to fresh water. The diet subjected to chemical analysis according to AOAC (1999).

\subsection{Blood Sampling}

Blood samples were collected at the end of the $4^{\text {th }}$ and the $8^{\text {th }}$ weeks of experimental time from the ear vein of all animals at the morning before accesses to feed and water. Citrated plasma (in a ratio of 1 volume sodium citrate (3.8\%): 9 volumes blood) was obtained for determination of certain haemostatic parameters.

\subsection{Measurements}

For monitoring of the haemostatic mechanisms, both extrinsic and intrinsic pathways were investigated through measurement of Prothrombin Time (PT) and Activated Partial Thromboplastin Time (APTT) according to Poller (1980) and Munteau et al. (1992), respectively. Fibrinogen concentration and activities of individual coagulation factors VII, IX and X were determined according to Dacie and Lewis (1984) using a commercial reagents 
manufactured by "Diamed-Swiss" obtained from "Biogen-Company, Egypt" and coagulation analyzer manufactured by "bio-Mereux company-France". Clotting factors activities were expressed as a \% of normal pooled plasma collected from rabbits of different ages and sexes.

\subsection{Statistical analysis:}

Data for all variables were subjected to ANOVA as a completely randomized design according to Snedecor \& Cochran (1982). Means were compared by Least Significant Difference (LSD) test at $\mathrm{P}<0.05$ (Steel \&Torrie, 1980).

\section{Results}

\subsection{Effects of feed additives on prothrombin time (PT) and Activated partial thromboplastin time (APTT)}

Table 1. Shows that no significant differences were recorded in PT and APTT of both supplemented groups at the end of $4^{\text {th }}$.week of supplementation when compared to control. However, a significant increase in the values of PT and APTT were detected in salinomycin supplemented group vs control and kemzyme supplemented groups at the end of the $8^{\text {th }}$ week of supplementation.

Table1. Prothrombin time (PT) and activated partial thromboplastin time (APTT) of rabbit bucks which received Kemzyme or Salinomycin feed additives for 8 successive weeks

\begin{tabular}{lllll}
\hline Parameter & PT (sec.) & \multicolumn{3}{l}{ APTT (Sec.) } \\
\hline Time/week & $4 \mathrm{w}$ & $8 \mathrm{w}$ & $4 \mathrm{w}$ & $8 \mathrm{w}$ \\
Control & $14.40 \pm 0.51$ & $13.0 \pm 0.42^{\mathrm{a}}$ & $48.5 \pm 2.41$ & $44.4 \pm 2.50^{\mathrm{a}}$ \\
Kemzyme & $15.20 \pm 0.90$ & $12.01 \pm 0.20^{\mathrm{a}}$ & $50.0 \pm 3.02$ & $45.10 \pm 1.37^{\mathrm{a}}$ \\
Salinomycin & $15.00 \pm 0.95$ & $17.0 \pm 0.30^{\mathrm{b}, \mathrm{c}}$ & $52.0 \pm 3.00$ & $57.1 \pm 2.20^{\mathrm{b}, \mathrm{c}}$ \\
LSD & N.S & 2.90 & N.S & 7.00 \\
\hline
\end{tabular}

Values represent mean \pm SE, means within the same column having different letters are significantly different at $\mathrm{P}<0.01 ;$ N.S: non-significant.

\subsection{Effects of Feed Additives on Fibrinogen Concentration.}

Table 2 demonstrates that no significant change in fibrinogen concentration at the end of the $4^{\text {th }}$ week of the experiment was recorded in all supplemented groups vs control. Meanwhile, at the end of the $8^{\text {th }}$ week, fibrinogen concentration was significantly higher in kemzyme supplemented group vs control and salinomycin supplemented groups.

Table 2. Fibrinogen concentration in rabbit bucks which received Kemzyme or Salinomycin feed additives for 8 successive weeks

\begin{tabular}{lll}
\hline Parameter & \multicolumn{2}{l}{ Fibrinogen $(\mathrm{mg} \%)$} \\
\hline Time/week & $4 \mathrm{w}$ & $8 \mathrm{w}$ \\
Control & $285.0 \pm 10.20$ & $285 \pm 9.020^{\mathrm{a}}$ \\
Kemzyme & $292.0 \pm 11.50$ & $310 \pm 9.30^{\mathrm{b}, \mathrm{c}}$ \\
Salinomycin & $278.0 \pm 9.10$ & $290 \pm 8.90^{\mathrm{a}}$ \\
LSD & N.S & 20.00 \\
\hline
\end{tabular}

Values represent mean \pm SE, means within the same column having different letters are significantly different at $\mathrm{P}<0.01 ;$ N.S: non-significant.

\subsection{Effects of Feed Additives on Individual Coagulation Factors Activities}

Table 3 shows the effects of different feed additives on the activities of blood clotting factors VII, IX and X of rabbit bucks during the $4^{\text {th }}$ and the $8^{\text {th }}$ weeksof the experimental period. No significant changes were recorded in the activities of all measured clotting factors at the end of the $4^{\text {th }}$ week of the experiment. While at the end of $8^{\text {th }}$ 
week, the activities of clotting factors VII, IX and X were significantly lowered $(\mathrm{P}<0.01)$ in bucks received salinomycin as compared to control and kemzyme supplemented groups.

Table 3. Factors VII, IX and X activities in rabbit bucks which received Kemzyme or Salinomycin feed additives for 8 successive weeks

\begin{tabular}{lllllll}
\hline Parameter & $\begin{array}{l}\text { Fac. VII } \\
\text { (\% activity) }\end{array}$ & \multicolumn{3}{l}{$\begin{array}{l}\text { Fac. IX } \\
\text { (\% activity) }\end{array}$} & \multicolumn{2}{l}{$\begin{array}{l}\text { Fac. X } \\
\text { (\% activity) }\end{array}$} \\
\cline { 2 - 7 } Time/week & $4 \mathrm{w}$ & $8 \mathrm{w}$ & $4 \mathrm{w}$ & $8 \mathrm{w}$ & $4 \mathrm{w}$ & $8 \mathrm{w}$ \\
\hline Control & $63.6 \pm 2.80$ & $66.8 \pm 2.40^{\mathrm{a}}$ & $55.9 \pm 1.90$ & $58.8 \pm 2.40^{\mathrm{a}}$ & $66.2 \pm 1.28$ & $73.5 \pm 2.90^{\mathrm{a}}$ \\
Kemzyme & $66.5 \pm 2.90$ & $69.7 \pm 2.01^{\mathrm{a}}$ & $58.0 \pm 2.00$ & $58.4 \pm 3.040^{\mathrm{a}}$ & $70.0 \pm 2.00$ & $72.10 \pm 3.30^{\mathrm{a}}$ \\
Salinomycin & $69.5 \pm 3.01$ & $52.4 \pm 2.10^{\mathrm{b}, \mathrm{c}}$ & $54.0 \pm 2.02$ & $44.3 \pm 2.70^{\mathrm{b}, \mathrm{c}}$ & $68.0 \pm 1.80$ & $57.10 \pm 3.01^{\mathrm{b}, \mathrm{c}}$ \\
LSD & N.S & 10.50 & N.S & 13.00 & N.S & 12.60 \\
\hline
\end{tabular}

Values represent mean \pm SE, means within the same column having different letters are significantly different at $\mathrm{P}<0.01$. N.S: non - significant clotting factors activities were expressed as a $\%$ of normal pooled plasma.

\section{Discussion}

The present study was carried out to investigate the effect of some feed additives (Kemzyme and Salinomycin) on haemostatic mechanism and some haemostatic parameters in bucks.

Results obtained indicated that the haemostatic mechanism of all supplemented bucks was not influenced by the supplementation during the first four weeks of the experiment. Later on, and at the end of the $8^{\text {th }}$ week of the experiment a state of hypocoagulability was detected in bucks supplemented with Salinomycin. Hypocoagutability was manifested by a significant elongation in PT and APTT, decreased activities of coagulation factors, VII, IX and X..

Kemzyme supplementation was not associated with any significant alterations concerning haemostatic mechanisms or coagulation factors activities. Such finding, did not agree with that of Saleh et al. (2008) who found that supplementing ration of growing turkey toms with Kemzyme was associated with an obvious blood hypercoagulability condition that was accompanied by an accelerated PT and APTT together with a significant activation of coagulation factors I, VII, IX and X.

The difference in the obtained results could be attributed to breed difference and the differences in gut environments between turkey and rabbits. Meanwhile, the significant increase that recorded in PT and APTT in Salinomycin supplemented group in the present study might be a reflection of decreased clotting factors activities regulating their values as described by Belleville et al. (1982).

Barragry (1994) reported that Salinomycin is one of polyether antibiotic group and was found to exert its ionophorous properties on the cations transport through the cell membrane of animal tissues, bacteria and protozoa. Heil et al. (1984) determined the tissue residues of Salinomycin in rabbits. They reported that at zero withdrawal day, the liver contained $10 \mathrm{ppm}$ Salinomycin. Moreover, Atef et al. (1993) concluded that the highest concentration of Salinomycin was in liver, kidneys, muscles, fat and heart. They also mentioned that the toxic effect induced by Salinomycin may be due to its action on cellular cations homeostasis (Westley, 1983) or residual effects on tissue cells (Dimenna et al., 1990).

The adverse effect induced by salinomycin on the haemostatic mechanism of bucks which was recorded after 8 weeks of treatement meight be due to the toxic effect of Salinomycin and / or its residues on tissue cells, particularily liver cells, which affect its capability for protein synthesis, including coagulation proteins, leading to insufficient coagulation mechanism (hypocoagulability) that could be facilitate internal bleeding disorders which is fatal if occurred in vital organs. Also, intramuscular bleeding meight be unacceptable which renders the rabbit meat unmarketable causing economic losses. On the other hand, Abaza and Omara (2011) were found that Supplementation of Kemzyme to the diet of rabbit improved the liver functions keeping AST and ALT values within normal . The same results were confirmed by Abd El-Fattah et al. (2003) and Ibrahim and Saleh (2005). These findings may explaine the protective role of multi-enzymes feed additive on liver function maintaining normal haemostatic mechanism. 
In conclusion, enzyme feed additive (Kemzyme) was more safer to be used as a growth promoters in rabbits. Salinomycin feed additive should be not used more than 4 weeks to avoid its adverse effect on haemostasis and the subsequent economic losses.

\section{References}

Abaza, I. M., \& Omara, M. E. (2011). Effect of dietary corn cobs and enzymes supplementation on growing rabbits performance. J. Product. and Dev., 16(3), 507-511.

Abd El-Fattah, S. A., El-Hommosany, Y. M., \& Maie, F. M. (2003). Response of quail chicks to diet quantitative immunological and physiological aspects. Egypt. Poultry Sci., 23, 421-440.

AOAC. (1999). Association of Official Analytical Chemists. Official Methods of Analysis (16th ed., vol. 2). Washington D.C., USA.

Atef, M., Youssef, S. A., Ramadan, A., \& Abou-El-sooud, K. (1993). Kinetic disposition, systemic bioavailability and tissue distribution of salinomycin in chickens. Res. Vet. Scie., 54, 179-183.

Barragry, T. B. (1994). Growth promoting agents. In veterinary drug therapy, ed. Lea and febiger (pp. 579-649). London, Munich, Sydney and Tokyo.

Belleville, J., Carnillon, B., Baguet, P., \& Eloy, R. (1982). Haemostasis, blood coagulation and fibritnolysis in the Japanes quail. Comp. Biochem. Physiol. A. Physiol., 71, 219-230.

Bogosavljević, Bošković, S., Rakonjac, S., Dosković, V., \& petrović, D. M. (2012). Broiler rearing systems: $a$ review journal, 68, 217-228.

Butaye, L. A., Devries, L. A., \& Freddy, H. (2003). Antimicrobial growth promoters used in Aimal feed: Effects of Less Well known Antibiotics on Gram-Positive Bacteria. Laboratory of Veterinary Bacteriology and Mycology, Department of Pathology, Faculty of veterinary Medicine, University of Chent, Belgium.

Chapman, H., Skinner, J., Waldroup, P., \& Sehleifer, J. (1993). Research note: does compensatory growth occure following with drawal of salinomycin from the diet of broilers? Poult. Sci., 72, 383-386.

Cheeke, P. R., Sanchez, W. K., \& Patton, N. M. (1985). Protein requirements for optimal growth and reproduction for rabbits. Nutr.Abst. Rev., 56, 331 .

Cowieson, A. J. (2005). Factors that affect the nutritional value of maize for broilers. Animal Feed Science and Technology, 119, 293-305.

Cowieson, A. J., \& Ravindran, V. (2008). Effect of exogenous enzymes in maize-based diets varying in nutrient density for young broilers; major fattening results and meat quality traits.World's Poultry Science growth performance and digestibility of energy, minerals and amino acids. Britsh poultry science, 49, 37-44.

Dacie, J. V., \& Lewis, S. M. (1984). Practical hematology (6th ed.). Churchill Living stone, Edinburgh London and New York.

Dimenna, G. P., Lyon, F. S., Creegan, J. A., Wright, G. J., Wilkes, L. C., Johnson, D. E., \& Szymanski, T. (1990). Salinomycin residues and their ionophoricity in pig tissues. J. Agric. Food Chemistry, 38(4), 1029-1032.

Falcao-e-Cunha, L., Castro-Solla, L., Maertens, L. M., Marounek, M., Pinheiro, V., Freire, J., \& Mour, J. L. (2007). Alternatives to antibiotic growth promoters in rabbit feeding: a review. World Rabbit Science, 15, 127-140.

García, A. I., García, J., Corrent, E., Chamorro, S., García-Rebollar, P., De Blas, J. C., \& Carabaño, R. (2005). Effect of rabbit age, type of protein and feed enzyme addition on the apparent dry matter and crude protein digestibility of rabbit feed. In Proc. 11émes Journées de la RechercheCunicole. 2005 November, Paris, France.

Ghazi, S., Rooke, J. A., Galbrath, H., \& Bedford, M. R. (2002). The potential for the improvement of nutritive value of soya-bean meal by different protease in broiler chicks and broiler cookerels. British Poultry Science, $43,70-77$.

Hasanat, M. S., Hossain, M. E., Mostari, M. P., \& Hossain, M. A. (2006). Effect of concentrate supplementation on growth and reproductive performance of rabbit under rural condition.Bangl. J. Vet. Med., 4(2), 129-132.

Heil, K., Peter, F., \& Cieleszky, V. (1984). Thin layer bioautographic assay for the detection of salinomycin in rabbit tissue. J. Agric. Food chem., 32, 997-998.

Hruby, J. M. (2005). Nutritional solutions beyond AGPs. Anti-microbial growth promoters: Worldwide Ban on the Horizon, the Netherlands. 
Ibrahim, K. A., \& Saleh, E. S. (2005). Response of male broiler chicks to skip a day feeding Programs. Egypt. Poultry Sci., 25, 351-37

Lui, K. (2001). KEMZYME (dry and amino acid digestability). Kem. Tek Asia, 1, 2.

Munteau, W., Finding, K., \& Leschnik, B. (1992). Partial thromboplastin time are longer in healthy children than in adults. Thromb. Haemorrh. Dis., 6, 23-25.

Officer, D. I. (2002). Feed enzymes. In J. P. F. Mello (Ed), Farm Animal Metabolism and Nutrition (pp. 405-426). (CAB International).

Onderci, M., Sahin, N., Sahin, K., Cikim, G., Aydin, A., Ozercan, I., \& Aydin, S. (2006). Efficacy of supplementation of $\alpha$-amylase-producing bacterial culture on the performance, nutrient use, and gut morphology of broiler chickens fed a corn-diet. Poultry Science, 85, 505-510.

Peter, T. U., Fulton, R. M., Roberson, K. D., \& Orth, M. W. (2002). Effect of antibiotics on in vitro and in vivo avian cartilage degradation. Department of animal science Michigan state university, East Lansing I.S.A. Journal-arrticle, 46(1), 75-86.

Poller, R. L. (1980). Laboratory control of anticoagulant therapy. Thromb.Haemost., 12, 13-19.

Saleh, S.Y., Attia, K. A., Sawiress, F. A., Zaki, A. A., \& Nassa, M. M. (2008). Alterations of some homeostatic parameters of turkey toms supplemented with multi-enzyme feed additive $7^{\text {th }}$ international symposium on turkey diseases. Berlin, $19^{\text {th }}-21^{\text {st }}$ June.

Snedecor, C.W., \& Cochran, W. C. (1980). Statistical Method (7th ed Ames). Iowa state university press.

Steel, R. G., \& Torrie, J. H. (1980). Principles and procedures of statistics (2nd ed.). New York: McGraw-Hill, Book, Co, Inc.

Tuoying, A. O. (2005). Exogenous enzymes andorganic acids in the nutrition of broiler chicks: effects on growth performance and in vitro and in vivo digestion. Ph.D.Thesis. The graduate School University of Kentucky.

Westley, J. W. (1982). Notation and classification. In J. W. Westley (Eds.), Polyether antibiotics: naturally occurring acid ionospheres, vol. 1. Biology (pp. 1-20). New York, N.Y.: Marcel Dekker, Inc.

Zakaria, H. A. H., Jalal, M. A. R., \& Abu Ishmais, M. A. (2010). The influence of supplemental multi-enzyme feed additive on the performance, carcass characteristics and quality traits of broiler chickens. International Journal of Poultry science, 9(2), 126-133.

\section{Copyrights}

Copyright for this article is retained by the author(s), with first publication rights granted to the journal.

This is an open-access article distributed under the terms and conditions of the Creative Commons Attribution license (http://creativecommons.org/licenses/by/3.0/). 